\title{
Article
}

\section{Condom-use negotiation, alcohol consumption, and HIV-risk sexual behavior among female sex workers in Kupang, East Nusa Tenggara, Indonesia: A cross-sectional study}

\author{
Khumaidi, ${ }^{1}$ Sri Yona, ${ }^{2}$ Agung Waluyo² \\ ${ }_{1}^{1}$ PELNI Nursing Academy of Jakarta, Jakarta; ${ }^{2}$ Department of Medical Surgical Nursing, Faculty of Nursing, \\ Universitas Indonesia, Depok, West Java, Indonesia
}

\begin{abstract}
Background: Female Sex Workers (FSW) play a crucial part in HIV transmission. Having unprotective condom during sexual activity can lead to HIV infection. Having lower power in condom negotiation with client can lead FSW not to using condoms during the sexual act. Alcohol consumption was also mediated HIV risk behavior among FSW. This study aimed to evaluate the relationship between condom use-negotiation, alcohol consumption and HIV-risk sexual behavior among female sex workers (FSW) in Kupang.

Design and Methods: A cross-sectional study was conducted with 125 FSWs aged 18 to 60 years recruited from Yayasan Tanpa Batas Kupang with consecutive sampling. The data were analyzed using univariate and the Chi-square test.

Results: The majority of FSWs (61.6\%) reported had low negotiation condom use with their clients, about $77.6 \%$ reported high levels of alcohol consumption and 64.8\% had high-risk sexual behavior. Condom-use negotiation (p-value: 0.003 ) and alcohol consumption ( $\mathrm{p}$-value: 0.037) were found to be significantly associated with HIV-risk sexual behavior.

Conclusions: Future interventions on HIV prevention should focus on empowering young FSWs with condom negotation skills in order to increase condum use. It is also recommended to include information about alcohol consumption and it's relationship wit HIV-risk behavior in order to have better health outcomes for FSW.
\end{abstract}

\section{Introduction}

Human Immunodeficiency Virus (HIV) is a major global health issue. ${ }^{1}$ Data from The Joint United Nations Programme On HIV and AIDS (UNAIDS) reported that people living with HIV/AIDS had reached more than 36.7 million people in 2016 with the main route of transmission through sex among heterosexuals. $^{2}$

Based on Directorate General of Disease Prevention and Control, the number of new cases in Indonesia from January to March 2017 was 10,376 people and the highest risk factor for HIV transmission was heterosexual sexual intercourse. ${ }^{3}$ Kupang is one of the regions in Indonesia with increased the numbers of HIV cases. Based on data from January to December 2016, there were 235 new HIV cases in Kupang. In 2017, new cases increased to 242 with the top risk factor from sexual intercourse (heterosexual). ${ }^{4}$ Female sex workers plays crucial part in HIV transmission. ${ }^{5}$ Having unprotective condom during sexual activity can lead to HIV infection. Having lower power in condom negotiation with client can lead FSW not to using condoms during sexual act. ${ }^{6,7}$ One of the high-risk sexual behaviors for HIV AIDS transmission is sex without a protection (condom). ${ }^{8}$ The high transmission of HIV and sexually transmitted diseases in FSWs is caused by the low negotiation on condom use, which affect the inconsistencies in the use of condoms. ${ }^{9}$

The ability to negotiate condom use among FSW is a contributing factor in offering clients safe sex. However, when FSW does not have the ability to negotiate condom use, it makes it easier to have unsafe sex. Prior research revealed that FSW who did not negotiate or did not have a good ability to negotiate safe sex reported inconsistent using condom with their clients. ${ }^{10}$

Alcohol consumption was also mediated HIV risk behavior among FSW. Based on some previous studies, excessive alcohol consumption tends to increase the decision to participate in risky sexual behavior, especially in the form of unsafe sex. ${ }^{6}$ Berry and Johnson revealed that alcohol use leads to an increase in the possibility of having unprotected sex. ${ }^{11}$

Knowing the risky sexual behavior of female sex workers and their relationship to the negotiation skills of condom use and alcohol consumption is essential to determine appropriate interventions. This study aimed to evaluate relationship between condom-use negotiation, alcohol consumption and HIV-risk sexual behavior among FSWs.

Significance for public health

HIV-risk sexual behavior among Female Sex Workers (FSW) is significant for public health. FSW may become of the key population of the high transmission of HIV in FSWs and their clients is caused by HIV-risk sexual behavior. Condom-use negotiation, alcohol consumption may influence HIV-risk behavior among female sex workers, particularly in Kupang, Indonesia. Therefore, increasing ability of FSW to have good negotiation with clients. FSWs abilities to negotiate condom used by involving peers, and reduce alcohol consumption. In addition, routine counseling, education, and positive support from health workers, such as nurses, is needed to decrease HIV-risk sexual behavior among FSW. 


\section{Design and Methods}

\section{Study design}

This study used observational research design with cross sectional design.

\section{Setting and respondents}

This study was conducted from February, 2019, to March 2019 at one of NGO, Yayasan Tanpa Batas, in Kupang, East Nusa Tenggara Indonesia. This NGO provided several information and service for people with HIV, such as information about HIV/AIDS, reproductive health and also several issues related with HIV in Kupang.

\section{Sample}

The potential respondents were recruited by staff NGO, Yayasan Tanpa Batas Kupang using consecutive sampling. we carried out self-administered questionnaires survey of 125 FSW in Kupang, Province of East Nusa Tenggara.

The survey had three section. The first section asked questions about demographic variables: age, education, income, and marital status. The second section comprised question about HIV-risk sexual behavior, using the safe sexual behavior questionnaire (SSBQ) which consists of 24 items. The items are answered on a 4 likert scale ranging from 1 (never) to (very often). The third section about Condom-use negotiation was measured by the Condom Influence Strategy Questionnaire (CISQ), which consists of 7 items. The items are answered on a 4 likert scale ranging from 1 (never) to (very often). Alcohol consumption was measured by the Alcohol Use Disorders Identification Test (AUDIT) consisting of 10 items. All instruments have been tested for validity and reliability. SSBQ values were determined as reliable with Cronbach's alpha $(0,77)$, CISQ $(0,820)$ and AUDIT $(0,913)$. All respondents were informed that their participation is voluntary and guaranteed the privacy of the data. Once respondents agree to participate.

\section{Ethical consideration}

Ethics approval from The Ethics Committee of Faculy of Nursing Universitas Indonesia was obtained for this study (No.11/UN2.F12.D/HKP.02.04/2019).

\section{Data analysis}

Descriptive analysis was used to describe demographic characteristics (e.g age, educational level, income, marital status, risky sexual behavior, condom use negotiation and alcohol consumption. Bivariate analysis, chi-square test to measure the relationship between dependent and independent variable.

\section{Results}

Table 1 shows the majority of respondents were aged $18-40$ years $(88.8 \%)$, had low educational levels $(51.2 \%)$, had high income (73.6\%), were unmarried (61.6), had low levels of condom-use negotiation (61.6\%), consumed high levels of alcohol (77.6\%) and had sexual behavior at high risk of HIV (64.8\%).

The bivariate analysis shows that condom-use negotiation and alcohol consumption were significantly associated with risky sexual behavior (Table 2). We found that condom-use negotiation was positively associated with risky sexual behavior ( $\mathrm{p}$-value: 0.003, OR: 3.318). Respondents who had low condom-use negotiation skill were 3,318 times to have high-risk sexual behavior than those with high condom-use negotiation. The bivariate analisys also show that alcohol consumption was positively associated with risky sexual behavior (p-value: 0.037 , OR: 2.706). Respondents who had high level of alcohol consumption were 2.706 times to have high-risk sexual behavior than those with low level alcohol consumption.

Table 1. Characteristics of respondents $(n=155)$.

\begin{tabular}{lcc} 
Characteristics & f & $\%$ \\
Age (year) & & \\
$18-40$ & 111 & 88.8 \\
$41-60$ & 14 & 11.2 \\
Education & & \\
Low & 64 & 51.2 \\
High & 61 & 48.8 \\
\hline Income & & \\
Low & 33 & 26.4 \\
High & 92 & 73.6 \\
Marital status & & \\
Unmaried & 77 & 61.6 \\
Merried & 30 & 24 \\
Widowed & 18 & 14.4 \\
\hline Condom use negotiation & & \\
Low & 77 & 61.6 \\
High & 48 & 38.4 \\
Alcohol consumption & & \\
Low level & 28.4 \\
High level & 97 & 77.6 \\
\hline HIV-risk sexual behavior & & 35.2 \\
Low risk & 44 & 64.8 \\
High risk & 84 & \\
\hline
\end{tabular}

Table 2. Relationship between condom-use negotiation and alcohol consumption toward HIV-risk sexual behavior $(\mathbf{n}=155)$.

\begin{tabular}{|c|c|c|c|c|c|c|}
\hline \multirow[b]{2}{*}{ Variable } & \multicolumn{4}{|c|}{ Risky Sexual Behavior } & \multirow[t]{2}{*}{ OR } & \multirow[t]{2}{*}{ P-Value } \\
\hline & \multicolumn{4}{|c|}{ Low risk High risk } & & \\
\hline \multicolumn{7}{|c|}{ Condom use negotiation } \\
\hline High & 25 & 52.1 & 23 & 47.9 & 3.3 & $0.003^{*}$ \\
\hline Low & 19 & 24.7 & 58 & 75.3 & & \\
\hline \multicolumn{7}{|c|}{ Alcohol consumption } \\
\hline High level & 15 & 53.6 & 13 & 46.4 & 2.7 & $0.037^{*}$ \\
\hline Low level & 29 & 29.9 & 68 & 70.1 & & \\
\hline
\end{tabular}

*level of significant : $<0,05$ 


\section{Discussion}

The majority of respondents had low negotiation skills (61.6\%) and among $75.3 \%$ of respondents with low negotiation skills had high-risk sexual behaviors. According to Exavery et al., 2012, condom-negotiation skills effect the use condoms during sex. ${ }^{10}$ Individuals with low condom-negotioation skills experience inconsistent use of condoms. ${ }^{11}$ The negative impact of low condom-negotiation skill and high-risk sexual behavior is the increased transmission of HIV and sexually transmitted diseases in FSWs and their clients. ${ }^{9}$ Statistically, there was a significant relationship between the negotiation of condom use and HIV-risk sexual behavior among FSWs. This is also supported by several previous studies showed the skill of negotiating condom use was a significant factor in risky sexual behavior among FSWs. ${ }^{12,13}$

Study by Afiyanti and Solberg in Indonesia, women still have lower power in their relationship, particularly related with condom use. Condoms are still taboo, and women feel "ashamed" to their use, although with their husbands. Women accept their roles as a mothers and good housewife, who does not argue with their husbands, particularly about condom use for men. ${ }^{14}$ For FSWs, they have less power to negotiate condom use with their clients. ${ }^{15}$ Several studies in Indonesia showed lower rates of condom use among FSWs. ${ }^{16-18}$ For example, a study by Basuki about FSWs in Jakarta show that Only 5.8\% of sex workers consistently used condoms for a two-week period of observation. The main reason that they did not use condom because the beliefs that boyfriends, native indonesians and healthy-looking clients can not spread STDs. Another reason stated was that sex workers had already taken other preventive measures, like taking antibiotics before having sex. ${ }^{18}$

Research conducted by Bui et al. in Cambodia revealed that FSWs who did not negotiate or did not have good skills in safe sex were 4.6 times less likely to use condoms with their clients. ${ }^{15}$ Other research by Exavery et al. showed that respondents who are confident in negotiating condom use with their sex partners are 3.1 times more efficient in using condoms compared with women who do not have confidence in negotiating condom use. ${ }^{19}$ Similiar study in Indonesia conducted by Irmayati, Yona, Waluyo among women in Indonesia revealed that $56,7 \%$ have unsafe sex behavior. One contributing factor is weak negotiation skill related their partner's condom use and lack of knowledge about HIV/AIDS. ${ }^{20}$

Good negotiation skills will increase effective communication regarding condom use, and make it easier for FSWs to persuade clients to practice safe sex. ${ }^{21}$ Negotiation before sex will increase FSWs' persuasive efforts to convince clients to have safe sex by reaching an agrement throught joint decision-making. ${ }^{22}$ Conversely, a lack of negotiation skills makes FSWs accept client demands for unprotected sex. ${ }^{23}$ Lack of condom negotiations can affect consistent of condom use.

Economic is the main contributing factor for FSWs' risky sexual behavior in Kupang. Low economic status and the higher costs of living encourage FSWs to accept clients' offers for unprotected sex. ${ }^{18,24}$ Previous research conducted by Januraga in Bali Indonesia found two main logics for not using condom: economic reason and romantic relationships over condom use. Feeling secure and trust their clients is the underline reason for these FSWs did not use condom in Bali. ${ }^{25}$

The study also revealed that $77.6 \%$ of FSWs had high levels of alcohol consumption. Similar research revealed that around $70 \%$ of FSWs reported consuming alcohol at high level. ${ }^{26}$ Consuming alcohol at high level affects sexual behaviors, including sex without condoms.

The high level of alcohol consumption among FSWs is caused by several factors. Most of them report that clients generally force them to use alcohol; bar or cabaret managers also demand they drink. ${ }^{27}$ In addition, some FSWs become dependent on alcohol consumption, and they need to purchase alcohol can cause them to accept client demands for unprotected sex. ${ }^{27}$

Study results found a significant relationship between alcohol consumption and HIV-risk sexual behavior among FSWs. Some previous studies support these results. Other research conducted that consuming alcohol was significantly associated with the incidence of sexually transmitted diseases and unprotected sexual behavior. ${ }^{26}$ FSWs with high AUDIT scores tend to have unprotected sex with their clients compared to FSWs with low AUDIT scores. ${ }^{28}$

Alcohol use before and during sexual intercourse is associated with damage to the behavioral abilities needed to negotiate condom use. Alcohol use can cause a decrease in the desire to use condoms, lower ability to remember to use them, and decrease and the capability to use them properly. In addition, sexual intercourse under the influence of alcohol can reduce self-control of sexual behaviors, leading to impulsive and risky sexual behavior. ${ }^{29}$

Study conducted by Safika showed that alcohol consumption among FSWs in Indonesia is caused by the invitation and demands from clients. ${ }^{17}$ This situation led sexual behavior under influence of alcohol. Similiar to study in Tanzania, clients usually buy alcohol for FSWs to indicate they are interested in getting sexual services. ${ }^{30}$ Cultural factors in Kupang that include consuming traditional drinks (sopi) have a major influence on HIV-high risk transmission through sexual intercourse. The absence of regulations to restrict consumption of traditional alcoholic drinks in Kupang also contributed to the increase of alcohol consumption among FSWs and their clients. As a result, health promotion programs that highlight the negative effect of alcohol consumption among FSWs and their clients should be routine and continuous.

\section{Conclusions}

Based on study results, it was found that low condom-use negotiation and high level of alcohol consumption can affect HIVrisk sexual behavior among FSWs. Therefore, it is necessary to prioritize interventions that increase FSWs abilities to negotiate condom used by involving peers, and reduce alcohol consumption. It is essential to include level of non harm alcohol consumption in education material for FSWs before serving their clients. This is as one way to reduce the risky sexual behaviors of FSW. In addition, routine counseling, education, and positive support from health workers, such as nurses, is needed to decrease FSWs high risk sexual behaviors. 
Correspondence: Sri Yona, Department of Medical Surgical Nursing, Faculty of Nursing, Universitas Indonesia, Jalan Prof. Dr. Bahder Djohan, UI Depok Campus, West Java 16424, Indonesia.

Tel. +62 2178849120 - Fax. +62 217864124 .

E-mail: sriyona@ui.ac.id

Key words: Alcohol consumption; condom-use negotiation; female sex worker; HIV; risk sexual behavior.

Contributions: K, concept and design, undertook the data collection, analysis and interpretation of data, drafting and revision manuscript; $\mathrm{SY}$ and $\mathrm{AW}$, concept and design, data analysis, proofread manuscript, critical revision of manuscript, final approval.

Conflict of interest: The authors declare there are no conflicts of interests.

Acknowledgments: The authors would like to thank all respondents who have been involved in this study, and all staff at Yayasan Tanpa Batas Kupang.

Institutions where the research was carried out: Yayasan Tanpa Batas Kupang

Funding: This study was supported by the Universitas Indonesia PITTA B 2019 Grant Number NKB0502/UN2.R3.1/HKP.05.00/2019.

Ethics approval: This study was approved by The Ethics Committee of Faculty of Nursing Universitas Indonesia was obtained for this study with No.11/UN2.F12.D/HKP.02.04/2019. All participants signed the informed consent.

Availability of data and material: Available from the corresponding author at reasonable request

Conference presentation: This final manuscript has been presented at $7^{\text {th }}$ Virtual Biennial International Nursing Conference, Faculty of Nursing, Universitas Indonesia on September $24^{\text {th }}$, October $30^{\text {th }}$, November $16^{\text {th }} 2020$.

Received for publication: 3 December 2020.

Accepted for publication: 26 February 2021.

oCopyright: the Author(s), 2021

Licensee PAGEPress, Italy

Journal of Public Health Research 2021; 10(s1):2334

doi:10.4081/jphr.2021.2334

This work is licensed under a Creative Commons Attribution NonCommercial 4.0 License (CC BY-NC 4.0).

\section{References}

1. Melhuish A, Lewthwaite P. Natural history of HIV and AIDS. Medicine 2018;46:356-61.

2. UNAIDS. UNAIDS Data 2017. 2017. Available from: https://www.unaids.org/en/resources/documents/2017/2017_d ata book

3. Ministry of Health of the Republic of Indonesia. [Laporan perkembangan HIV, AIDS dan PIMS triwulan I tahun 2017 (Report on the progress of HIV, AIDS and PIMS for the first quarter of 2017)].[in Indonesian]. Ministry of Health of the Republic of Indonesia; 2017. Available from: http://kpakotabandung.or.id/book/laporan-triwulan-1-2017/

4. East Nusa Tenggara Health Office. [Profil kesehatan Nusa Tenggara Timur tahun 2017 (Health profile of East Nusa Tenggara in 2017)].[in Indonesian]. Kupang: East Nusa
Tenggara Health Office; 2017. Available from: http://dinkes.nttprov.go.id/index.php/publikasi/publikasi-datadan-informasi

5. Nasronudin. [HIV \& AIDS: pendekatan biologi molekuler, klinis dan sosial (HIV \& AIDS: molecular, clinical and social biological approaches)].[in Indonesian]. 2nd ed. Surabaya: Airlangga University Press; 2014.

6. Courtney LP, Goco N, Woja J, et al. HIV prevalence and behavioral risk factors in the Sudan People's Liberation Army: data from South Sudan. PLoS One 2017;12: e0187689.

7. SeyedAlinaghi SA, Farhoudi B, Ghodrati S, et al. HIV-related risk behaviors among male inmates of Tehran, Iran. Asian Pac J Trop Dis 2016;6:339-40.

8. AIDS Prevention Commission. [Strategi dan rancana aksi nasional 2015-2019: penanggulangan HIV dan AIDS di Indonesia (Strategy and national action plan 2015-2019: HIV and AIDS prevention in Indonesia)].[in Indonesian]. Jakarta: AIDS Prevention Commission; 2015. Available from: http://kpakotabandung.or.id/book/strategi-dan-rencana-aksinasional-2015-2019-kpan/

9. Kamal SMM, Hassan CH, Salikon RH. Safer sex negotiation and its association with condom use among clients of female sex workers in Bangladesh. Asia Pac J Public Health 2015;27:NP2410-22.

10. Exavery A, Kanté AM, Jackson E, et al. Role of condom negotiation on condom use among women of reproductive age in three districts in Tanzania. BMC Public Health 2012;12:1097.

11. Berry MS, Johnson MW. Does being drunk or high cause HIV sexual risk behavior? a systematic review of drug administration studies. Pharmacol Biochem Behav 2018;164:125-38.

12. Grosso AL, Lei EL, Ketende SC, et al. Correlates of condom use among female sex workers in The Gambia: results of a cross-sectional survey. PeerJ 2015;3:e1076.

13. Urada LA, Morisky DE, Pimentel-Simbulan N, et al. Condom negotiations among female sex workers in the Philippines: environmental influences. PLoS One 2012;7:e33282.

14. Afiyanti Y, Solberg SM. "It is my destiny as a woman": on becoming a new mother in Indonesia. J Transcult Nurs 2015;26:491-8.

15. Bui TC, Markham CM, Tran LT, et al. Condom negotiation and use among female sex workers in Phnom Penh, Cambodia. AIDS Behav 2013;17:612-22.

16. Megaputri PS, Sawitri AAS, Wirawan DN. [Negosiasi dan determinan pemakaian kondom oleh pekerja seks di Kota Denpasar (Negotiation and determinants of condom use by sex workers in Denpasar City)].[Article in Indonesian]. Public Health and Preventive Medicine Archive 2016;4:3-11.

17. Safika I, Levy JA, Johnson TP. Sex work venue and condom use among female sex workers in Senggigi, Indonesia. Cult Health Sex 2013;15:698-613.

18. Basuki E, Wolffers I, Devillé W, et al. Reasons for not using condoms among female sex workers in Indonesia. AIDS Educ Prev 2002;14:102-16.

19. Exavery A, Kanté AM, Jackson E, et al. Role of condom negotiation on condom use among women of reproductive age in three districts in Tanzania. BMC Public Health 2012;12:1097.

20. Irmayati N, Yona S, Waluyo A. HIV-related stigma, knowledge about HIV, HIV risk behavior and HIV testing motivation among women in Lampung, Indonesia. Enferm Clin 2019;29:546-50.

21. Zabrocki C, Polutnik C, Jonbekov J, et al. Condom use and 
intimacy among Tajik male migrants and their regular female partners in Moscow. Cult Health Sex 2015;17:17-33.

22. Noar SM, Carlyle K, Cole C. Why communication is crucial: meta-analysis of the relationship between safer sexual communication and condom use. J Health Commun 2006;11:365-90.

23. Jie W, Xiaolan Z, Ciyong L, et al. A qualitative exploration of barriers to condom use among female sex workers in China. PLoS One 2012;7:e46786.

24. George G, Nene S, Beckett S, et al. Greater risk for more money: the economics of negotiating condom use amongst sex workers in South Africa. AIDS Care 2019;31:1168-71.

25. Januraga PP, Mooney-Somers J, Gesesew HA, Ward PR. The logic of condom use in female sex workers in Bali, Indonesia. Int J Environ Res Public Health 2020;17:1627.

26. Chersich MF, Bosire W, King'ola N, et al. Effects of hazardous and harmful alcohol use on HIV incidence and sexual behaviour: a cohort study of Kenyan female sex workers. Global Health 2014;10:22.
27. Tan SY, Melendez-Torres GJ. A systematic review and metasynthesis of barriers and facilitators to negotiating consistent condom use among sex workers in Asia. Cult Health Sex 2016;18:249-64.

28. White D, Wilson KS, Masese LN, et al. Alcohol use and associations with biological markers and self-reported indicators of unprotected sex in human immunodeficiency virus-positive female sex workers in Mombasa, Kenya. Sex Transm Dis 2016;43:642-7.

29. Lama TP, Kumoji EK, Ketlogetswe D, et al. Alcohol consumption and risky sexual behavior among persons attending alcohol consumption venues in Gaborone, Botswana. Prev Sci 2016;17:227-36.

30. Leddy AM, Kerrigan D, Kennedy CE, et al. 'You already drank my beer, I can decide anything': using structuration theory to explore the dynamics of alcohol use, gender-based violence and HIV risk among female sex workers in Tanzania. Cult Health Sex 2018;20:1409-23. 